\title{
A DADA drogprevenciós program hatékonyságvizsgálata hetedik évfolyamos általános iskolai tanulók körében
}

\author{
Danku Nóra ${ }^{1,2}$. Fekete Rita ${ }^{3}$. Fekete Sándor dr. ${ }^{4}$ - Boncz Imre dr. ${ }^{1}$ \\ ${ }^{1}$ Pécsi Tudományegyetem, Egészségtudományi Kar, Egészségbiztosítási Intézet, Pécs \\ ${ }^{2}$ Pécsi Tudományegyetem, Egészségtudományi Kar, Egészségtudományi Doktori Iskola, Pécs \\ ${ }^{3}$ Baranya Megyei Rendőr-fơkapitányság, Búnmegelőzési Osztály, Pécs \\ ${ }^{4}$ Pécsi Tudományegyetem, Klinikai Központ, Pszichiátriai Klinika, Pécs
}

\begin{abstract}
Bevezetés: A drogok fogyasztása a fiatalok körében nem ritka jelenség. Bizonyítottan hatékony iskolai drogprevenciós programokra van szükség.

Célkitüzés: Kutatásunk célja a rendőrségi DADA drogprevenciós program hatékonyságának feltárása volt.

Módszer: A kutatás a pécsi székhelyú Apáczai Csere János Általános Iskola és a pécsváradi Kodolányi János Általános Iskola diákjai körében végzett standard kérdő́ives vizsgálaton alapult.

Eredmények: A részt vevő diákok válaszait elemezve kiderült, hogy programot követôen 27\%-ról 37,3\%-ra nőtt azok aránya, akik „mindent tudnak”, és 5,6\%-ról 1,6\%-ra csökkent azoké, akik „semmit sem tudnak” a drogokról $(\mathrm{p}<0,001)$. A DADA-program hatására nem mutatkozott szignifikáns változás az énhatékonyság tekintetében $(\mathrm{p}=$ 0,364). Azzal az állítással azonban, hogy „Nagyon sokat tanultam a foglalkozásból”, illetve „Sok olyan kérdésre kaptam választ, ami már régóta foglalkoztatott”, mindössze a diákok kevesebb mint 60\%-a értett egyet.

Következtetés: A DADA-program összességében eredményesnek bizonyult. A program hatékonyságának értékelésekor figyelembe kell vennünk a részt vevő diákok társadalmi és kulturális hátterét is.

Orv Hetil. 2019; 160(23): 914-920.
\end{abstract}

Kulcsszavak: drogprevenció, hatékonyságvizsgálat

\section{Evaluation of the effectiveness of a DADA school-drug prevention program among seventh-grade students}

Introduction: Drug-taking habit is not infrequent in the young population. There is a need of proven effective drug prevention programs.

Aim: The aim of our study was to analyze the efficiency of the Hungarian Police's DADA school-drug prevention program.

Method: The research program was carried out by a standard questionnaire at Apáczai Csere János Primary School in Pécs and Kodolányi János Primary School in Pécsvárad.

Results: After analyzing the participating students' answers, the results showed that the rate of those, who "know everything" about drugs, increased from $27 \%$ to $37.3 \%$, and of those, who did "not know anything", decreased from $5.6 \%$ to $1.6 \%(\mathrm{p}<0.001)$. Regarding self-efficiency, the DADA program did not show any significant change $(\mathrm{p}=$ $0.364)$. However, less than $60 \%$ of the students agreed the statements: "I have learned a lot from the trainings" and "I received answers to several questions that I had been interested in earlier."

Conclusion: We can conclude that the DADA program was successful. Regarding the chosen reactions and opinions about the program, we have to consider the sociocultural background of the participants.

Keywords: drug prevention, effectiveness evaluation

Danku N, Fekete R, Fekete S, Boncz I. [Evaluation of the effectiveness of a DADA school-drug prevention program among seventh-grade students]. Orv Hetil. 2019; 160(23): 914-920.

(Beérkezett: 2019. január 15.; elfogadva: 2019. február 16.) 


\section{Rövidítések}

BOKA = Budapesti Orvostanhallgatók Kortársoktató Alapítványa; DADA = Dohányzás, Alkohol, Drog, AIDS; ESPAD = (European School Survey Project on Alcohol and Other Drugs) európai iskolavizsgálat a fiatalok alkohol- és egyéb drogfogyasztási szokásairól; „FÜGE” = Devianciaprevenciós Program

A fiatal populáció körében világszerte jelentős a drogfogyasztás [1-3]. A legfrissebb magyarországi ESPAD-kutatás felmérése szerint [4] a megkérdezett 9-10. évfolyamos diákok 26,8\%-a fogyasztott már életében valamilyen tiltott vagy legális drogot. A kábítószerek pedig jelentős népegészségügyi problémát jelentenek [5-8]. Az előbbiekben említett adatok is a drogprevenciós programok szükségességét jelzik, amelyek egyik legfontosabb színtere az iskola [9].

Az iskolai drogprevenciós programok hatékonyságával kapcsolatban sokan kételkednek [10-12], hiszen rendkívül kevés olyan programmal találkozunk, amelynek eredményességét tudományosan bizonyították [13-15]. A vizsgálatok ugyanakkor azt a tényt is visszatükrözik, miszerint a piacon számos sikertelen program is megtalálható [16-19]. Nemzetközi információk szerint jó néhány országban továbbra is a kutatásokkal nem alátámasztott beavatkozások a dominánsak $[20,21]$. Hazánkban szintén még mindig gyakori a csupán ismeretátadásra és elrettentésre koncentráló tartalmak előfordulási aránya [22], annak ellenére, hogy sok tapasztalat és Cochrane review azt igazolja, hogy nincs megelőző hatásuk [23-25]. Olykor az alaptalan iskolai prevenció ellenkező hatáshoz is vezethet, még inkább felkeltheti a diákok kíváncsiságát a drogokkal kapcsolatban. Az egészségügyben a prevenció kérdése a szakmai kérdéseken túlmutatóan jelentős gazdasági vonatkozásokkal is bír [2630].

Már 1998-tól kezdődően több vizsgálat igazolta, hogy az intézményi szereplők közül a rendőrség szerepe a legmeghatározóbb a drogmegelőzésben [22, 31-33]. Magyarországon a rendőrségnek közel két évtizede van tematikus általános iskolai (DADA) és középiskolai (ELLEN-SZER) kábítószer-megelőzési programja. A 2013/14-es tanévben e programokon összesen 40226 gyermek vett részt [34]. A Baranya Megyei Rendőr-főkapitányság Bünmegelőzési Osztályának a kutatásunk alapjául szolgáló programjai tanévenként mintegy 13500 gyermekhez, kizárólag drogprevenciós előadásai pedig közel 8000 diákhoz jutnak el. Nem kérdés tehát, hogy Baranya megyében a rendőrségnek kiemelkedő szerepe van a drogmegelözésben.

A jelen vizsgálat a „FÜGE” drogprevenciós program feltárására épülő 2012-es kutatásunk folytatása [35], melynek közvetlen célja a Baranya Megyei Rendőr-fókapitányság Bûnmegelőzési Osztálya által múködtetett DADA drogprevenciós program hatékonyságának feltárása. Törekvéseink között szerepel egyfajta nézőpontvál- tás elindítása, melynek két kulcspontja a meggyőző módon bizonyított prevenciós programok preferálása, illetve az értékelési kultúra létrehozása.

\section{Módszer}

A kutatás a programot befogadó intézmény, a pécsi székhelyű Apáczai Csere János Általános Iskola és a pécsváradi Kodolányi János Általános Iskola diákjai körében végzett standard kérdőíves vizsgálaton alapult. A vizsgálatba került iskolák vezetőinek, pedagógusainak prevencióval, kutatással szembeni magatartása konstruktív, kooperatív volt. A kutatás egy évtizedek óta múködő, rendőrségi drogprevenciós program hatékonyságát vizsgálta. Az adatgyüjtés az iskola engedélyét, a szülői beleegyező nyilatkozatok visszaérkezését, illetve a részt vevő diákok szóbeli tájékoztatását követően valósult meg. A válaszadás önkéntes, az adatszolgáltatás anonim volt.

A kérdőív forrása Paksi Borbála és Demetrovics Zsolt "A drogprevenciós gyakorlat megismerése" című könyvének I. számú melléklete volt [36]. A prekérdőív a minta szociokulturális hátterén kívül vizsgálta az ismeretek változását, az énhatékonyság alakulását, az észlelt kitettséget, az észlelt kockázatot, a prevenció akadályait, a segítségkérési hajlandóságot, azaz a drogprevenció általánosnak tekinthető célkitűzéseit. A posztkérdőívek tartalma túlnyomórészt megegyezett a prekérdőívével. A posztkérdőív ezen túlmenően tartalmazott olyan véleménykérdéseket vagy a programmal való elégedettséggel kapcsolatos kérdéseket is, melyek a programhatékonyságra, illetve a folyamatértékelésre vonatkoztak.

Az énhatékonyság minőségét négyfokozatú skála segítségével kérdeztük, ahol az l-es azt jelentette, hogy „egyáltalán nem jellemző”, a 4-es pedig azt, hogy „nagyon jellemző" [36]. A DADA-program különböző jellemzőinek értékelésekor az egyetértés mértékét a diákok hétfokú véleményskálán fejezték ki, ahol az l-es azt jelentette, hogy „egyáltalán nem ért egyet”, a 7-es pedig azt, hogy „teljes mértékben egyetért” [36].

A DADA-program által elérni kívánt célcsoport együttes nagysága 150 fó volt, melyből ténylegesen 126 diák vett részt a programban, így az elérési hatékonyság $84 \%$. A preadatfelvételben megkérdezett 126 diák személyében azonos a posztadatfelvétel sokaságával. Az adatfelvétel alapsokaságát tehát a DADA-programban részt vevő diákok képezték, így kutatásunk elemszáma 126 fő. A program és az adatfelvétel az iskolák tanárainak jelenléte nélkül, osztályfőnöki óra keretében valósult meg. A previzsgálat a program megkezdése előtt, azaz 2014. március 12-től 14-ig az Apáczai Csere János Általános Iskolában, április 10-én pedig a Kodolányi János Általános Iskolában zajlott. A posztvizsgálat a prevenciós program befejezését követô 10 napon belül, azaz 2014. április 16-ig folyamatosan történt. Adatainkat SPSS 20.0. statisztikai szoftverben (IBM Corporation, Armonk, NY, Amerikai Egyesült Államok) dolgoztuk fel, 
A minta összetételi sajátosságai a fóbb szociokulturális dimenziók mentén $(\mathrm{n}=126)$

\begin{tabular}{|c|c|c|}
\hline $\mathrm{Nem}$ & Elemszám & Megoszlás (\%) \\
\hline Fiú & 52 & 41 \\
\hline Lány & 74 & 59 \\
\hline Összesen & 126 & 100 \\
\hline Apák végzettsége & Elemszám & Megoszlás (\%) \\
\hline 8 általánosnál kevesebb & 0 & 0 \\
\hline 8 általános & 4 & 3 \\
\hline Szakmunkásképző & 45 & 36 \\
\hline Érettségi & 36 & 29 \\
\hline Diploma & 25 & 20 \\
\hline Nem tudja & 16 & 13 \\
\hline Összesen & 126 & 100 \\
\hline Otthon töltött esték száma & Elemszám & Megoszlás (\%) \\
\hline Egyet sem & 2 & 2 \\
\hline 1-2 estét & 6 & 5 \\
\hline 3-4 estét & 8 & 6 \\
\hline 5-6 estét & 44 & 35 \\
\hline Minden estét otthon tölt & 66 & 52 \\
\hline Összesen & 126 & 100 \\
\hline $\begin{array}{l}\text { A válaszadóval egy háztartásban élő } \\
\text { személyek }\end{array}$ & Elemszám & Megoszlás (\%) \\
\hline Egyedül élek & 0 & 0,0 \\
\hline Édesapám & 76 & 60,3 \\
\hline Nevelőapám & 22 & 17,5 \\
\hline Édesanyám & 116 & 92,1 \\
\hline Nevelőanyám & 3 & 2,4 \\
\hline Testvérem (testvéreim) & 91 & 72,2 \\
\hline Nagyszüleim, más rokonaim & 20 & 15,9 \\
\hline Nem rokon személy(ek) & 2 & 1,6 \\
\hline Intézetben élek & 0 & 0,0 \\
\hline
\end{tabular}

és 95\%-os valószínúségi szinten $(\mathrm{p}<0,05)$ páros t-próbát (paired-sample T-test) alkalmaztunk.

A DADA mozaikszó, amelyben a betúk jelentése: Dohányzás, Alkohol, Drog, AIDS. A DADA-program lényege, hogy a feladatot önként vállaló, 3-4 napos felkészítő tanfolyamon kiképzett hivatásos rendőr meg- határozott tematika és tananyag szerint 45 perces foglalkozást tart a tanulóknak. A DADA készség-, képességfejlesztő, helyes önértékelésre nevelő, önbecsülést építő, hosszú távú, komplex, ingyenes megelőzési program, melynek fó célja a jogkövető életmódra nevelés. A drogmegelőzési óra fó mondanivalója: tanuld meg a veszélyhelyzetet mindenkor FELISMERNI, a következményeket jól átgondolva helyesen DÖNTENI, ha kell, ELUTASÍTANI a neked ártó dolgokat; mindenképpen MONDD EL, hogy mi történt, és ha lehet, próbáld meg ELKERÜLNI az ilyen helyzeteket.

\section{Eredmények}

A 126 foóből 74 lány (59\%) és 52 fiú (41\%) töltötte ki kérdő́ivünket. A minta átlagéletkora 13,87 év volt. A vizsgálatban részt vevők apjának 36\%-ban szakmunkásképző, 29\%-ban érettségi és 20\%-ban diploma volt a legmagasabb iskolai végzettsége. Egy átlagos héten a minta 35\%-a 5-6 estét, 52\%-a minden estét otthon tölt. A válaszadók 13\%-a viszont legalább 3 este elmegy otthonról. A kutatásban részt vevők közül senki sem él intézetben, és csak két fó él nem rokon személyekkel. A megkérdezettek 2,4\%-a a nevelőanyjával (is), 16\%-a nagyszüleivel/más rokon személyekkel (is) és 18\%-a nevelőapjával (is) egy háztartásban lakik. A minta 60\%-a él édesapjával (is), és 72\%-a a testvérével (is). Édesanyjával (is) a válaszadók 92\%-a él (1. táblázat).

A „Szerinted te most mennyit tudsz a drogokról?” kérdésre adott válaszok eloszlása tekintetében a szándékoltnak megfelelő irányú szignifikáns különbséget figyelhettünk meg $(\mathrm{p}<0,001)$. A program lefutását követően 27\%-ról 37,3\%-ra növekedett azok aránya, akik úgy ítélték meg, hogy „mindent tudnak” a drogokról, amit szeretnének. A „sok mindent tudok, de még egy csomó minden érdekel" állítás tekintetében megfigyelhető a 32,5\%-ról 38,1\%-ra történő emelkedés, ami az ismeretekre vonatkozó kedvező tendencia mellett egyben a prevenciós programok iránti nyitottság jelenségére is utalhat. Kutatásunk eredményei alapján a keveset tudók aránya mintegy 10\%-kal csökkent (pre: 34,9\%; poszt: $23 \%)$. Ugyanakkor a program az egyáltalán nem tájékozottak arányában is jelentős változást ért el (pre: 5,6\%; poszt: 1,6\%) (2. táblázat).

2. táblázat |A „Szerinted te most mennyit tudsz a drogokról?” kérdésre adott válaszok eloszlása a DADA prevenciós program előtt és után

\begin{tabular}{|c|c|c|c|c|c|c|}
\hline & \multicolumn{4}{|c|}{ Posztfelvétel } & \multirow{2}{*}{$\begin{array}{c}\text { Összes } \\
\text { prefelvétel }\end{array}$} \\
\hline & & Mindent & Sokat, de még érdekli & Keveset & Semmit & \\
\hline \multirow{4}{*}{ Prefelvétel } & Mindent & 23,0 & 3,2 & 0,8 & & 27 \\
\hline & Sokat, de még érdekli & 5,6 & 25,4 & 1,6 & & 32,5 \\
\hline & Keveset & 7,9 & 7,1 & 19,8 & & 34,9 \\
\hline & Semmit & 0,8 & 2,4 & 0,8 & 1,6 & 5,6 \\
\hline \multicolumn{2}{|c|}{ Összes posztfelvétel } & 37,3 & 38,1 & 23 & 1,6 & 100 \\
\hline
\end{tabular}

DADA = Dohányzás, Alkohol, Drog, AIDS 
3. táblázat |Az énhatékonyság értékei a DADA-program előtt és után (négyfokozatú skála)

\begin{tabular}{|c|c|c|c|c|c|c|c|}
\hline \multirow{2}{*}{$\begin{array}{l}\text { Kérdés } \\
\text { Mennyire jellemzőek rád az } \\
\text { alábbi dolgok? }\end{array}$} & \multirow{2}{*}{$\begin{array}{l}\mathrm{AZ} \\
\text { egyetértés } \\
\text { foka }\end{array}$} & \multicolumn{2}{|c|}{ PRE } & \multicolumn{2}{|c|}{ POSZT } & & \\
\hline & & Elemszám & Megoszlás (\%) & Elemszám & Megoszlás (\%) & & \\
\hline \multirow{6}{*}{$\begin{array}{l}\text { Mindig sikerül megoldani } \\
\text { a problémáimat, ha nagyon } \\
\text { akarom. }\end{array}$} & 1 & 1 & 0,8 & 2 & 1,6 & & \\
\hline & 2 & 24 & 19 & 22 & 17,5 & & \\
\hline & 3 & 71 & 56,3 & 62 & 49,2 & & \\
\hline & 4 & 30 & 23,8 & 40 & 31,7 & & \\
\hline & Összesen & 126 & 100 & 126 & 100 & & \\
\hline & Átlag & \multicolumn{2}{|c|}{3,03} & \multicolumn{2}{|c|}{3,11} & T-próba & 0,240 \\
\hline \multirow{6}{*}{$\begin{array}{l}\text { Megfelelő erőfeszítéssel } \\
\text { majdnem minden } \\
\text { problémára találok } \\
\text { megoldást. }\end{array}$} & 1 & 2 & 1,6 & 1 & 0,8 & & \\
\hline & 2 & 27 & 21,4 & 25 & 19,8 & & \\
\hline & 3 & 61 & 48,4 & 72 & 57,1 & & \\
\hline & 4 & 36 & 28,6 & 28 & 22,2 & & \\
\hline & Összesen & 126 & 100 & 126 & 100 & & \\
\hline & Átlag & \multicolumn{2}{|c|}{3,04} & \multicolumn{2}{|c|}{3,01} & T-próba & 0,648 \\
\hline \multirow{6}{*}{$\begin{array}{l}\text { Bármi történik, általában } \\
\text { kezelni tudom a helyzetet. }\end{array}$} & 1 & 3 & 2,4 & 2 & 1,6 & & \\
\hline & 2 & 35 & 27,8 & 35 & 27,8 & & \\
\hline & 3 & 57 & 45,2 & 53 & 42,1 & & \\
\hline & 4 & 31 & 24,6 & 36 & 28,6 & & \\
\hline & Összesen & 126 & 100 & 126 & 100 & & \\
\hline & Átlag & \multicolumn{2}{|c|}{2,92} & \multicolumn{2}{|c|}{2,98} & T-próba & 0,356 \\
\hline
\end{tabular}

DADA = Dohányzás, Alkohol, Drog, AIDS

A DADA-program előtt a minta $23,8 \%$-ára, utána pedig a 31,7\%-ára nagyon jellemző volt, hogy mindig sikerül megoldani a problémáját, ha nagyon szeretné. Jellemző, hogy megfelelő erőfeszítéssel majdnem minden problémára talál megoldást a válaszadók $48,4 \%$-a a prekérdőívek, és 57,1\%-a a posztkérdőívek alapján. A programot megelőzően a 126 főből 57 före volt jellemző, hogy bármi történik is, kezelni tudja a helyzetet. A programot követően ugyanezen megállapításra már csak 53

4. táblázat |A DADA-programban részt vevő diákok véleménye a kapott információkról (hétfokozatú skála)

\begin{tabular}{lcccc}
\hline Kérdés & \multicolumn{3}{c}{ Mennyire értesz egyet az állításokkal? } \\
\cline { 2 - 5 } & $\begin{array}{c}\text { „Nagyon sokat tanultam } \\
\text { a foglalkozásból.” }\end{array}$ & $\begin{array}{c}\text { „Sok olyan kérdésre } \\
\text { kaptam választ, ami már } \\
\text { régóta foglalkoztatott.” }\end{array}$ \\
\hline $\begin{array}{l}\text { Az egyetértés } \\
\text { foka }\end{array}$ & Elemszám & $\begin{array}{c}\text { Megoszlás } \\
(\%)\end{array}$ & Elemszám & $\begin{array}{c}\text { Megoszlás } \\
(\%)\end{array}$ \\
\hline 1 & 2 & 1,6 & 12 & 9,5 \\
2 & 6 & 4,8 & 6 & 4,8 \\
3 & 4 & 3,2 & 12 & 9,5 \\
4 & 9 & 7,1 & 16 & 12,7 \\
5 & 13 & 10,3 & 20 & 15,9 \\
6 & 29 & 23 & 20 & 15,9 \\
7 & 63 & 50 & 40 & 31,7 \\
\hline Összesen & 126 & 100 & 126 & 100 \\
\hline Átlag & \multicolumn{5}{c}{5,89} & & \multicolumn{3}{c}{4,95} \\
\hline
\end{tabular}

DADA = Dohányzás, Alkohol, Drog, AIDS diák adott „jellemző” választ. Összességében elmondható, hogy a DADA-program esetében nem mutatkozott szignifikáns változás az énhatékonyság tekintetében $(\mathrm{p}=$ $0,364)$ (3. táblázat).

Azzal az állítással, hogy „Nagyon sokat tanultam a foglalkozásból”, illetve hogy „Sok olyan kérdésre kaptam választ, ami már régóta foglalkoztatott”, a diákok kevesebb mint fele $(40,8 \%)$ értett maradéktalanul egyet, és az inkább egyetértók aránya sem haladta meg a résztvevők 20\%-át. Azaz összességében a DADA-program információtartalmáról megközelítőleg a diákok $60 \%$-a vélekedett pozitívan. A program az első állítás esetében 5,89-es, a második állításnál pedig 4,95-ös átlagot ért el (4. táblázat).

\section{Megbeszélés}

Felmérésünk eredményeit összevetve Magyarországon az első hasonló célkitúzéssel rendelkező tanulmány eredményeivel [36], kutatásunk a DADA-program szakmai értékéről is információt ad a 2001-ben vizsgált hét drogprevenciós programhoz, továbbá az általunk 2012-ben feltárt „FÜGE” drogprevenciós programokhoz képest.

A DADA-programban részt vevő diákok 24,6\%-a érzékelte úgy a programot követően, hogy többet tud a drogokról, mint azt megelőzően. Az egyes programok között azonban e tekintetben különbségek mutatkoztak. Az átlaghoz képest nagyobb arányú elmozdulás jelentkezett a kábítószerekkel kapcsolatos szubjektív tudás megítélésében a „Kompánia”, a „Jól-lét”, illetve a DADA programokban részt vevók esetében, míg a BOKA, a 
A DADA-program eredményeinek összehasonlítása korábbi drogprevenciós programokkal: a tudás és az énhatékonyság tekintetében bekövetkező változások

\begin{tabular}{lccc}
\hline Programok & $\begin{array}{c}\text { A program elötti állapothoz képest } \\
\text { tudásukat nagyobbra értékelő tanulók } \\
\text { aránya (\%) }\end{array}$ & $\begin{array}{c}\text { Az énhatékonyság összesített pontértéke } \\
\text { a programok elótt és után }\end{array}$ \\
\cline { 3 - 4 } „Túnj el világ!” (Budapest, 2001) & 15,4 & Prefelvétel & Posztfelvétel \\
\hline Kompánia: Drognap (Budapest, 2001) & 30,6 & 3,04 & 2,93 \\
\hline Kék Pont program (Budapest, 2001) & 21,7 & 3,14 & 3,11 \\
\hline Jól-lét prevenciós óra (Budapest, 2001) & 28,5 & 3,44 & 3,16 \\
\hline BOKA (Budapest, 2001) & 14,5 & 3,07 & 3,05 \\
\hline „FÜGE” program (Pécs, 2012) & 20,2 & 3,17 & 3,19 \\
\hline DADA-program (Pécs, 2014) & 24,6 & 3,27 & 3,22 \\
\hline
\end{tabular}

BOKA = Budapesti Orvostanhallgatók Kortársoktató Alapítványa; DADA = Dohányzás, Alkohol, Drog, AIDS; „FÜGE” = Devianciaprevenciós Program

„Tứnj el világ!” és a „FÜGE” programok résztvevői közül csak mintegy $15-20 \%$ [36] tapasztalta ismereteinek növekedését (5. táblázat). Ehhez a részhez kívánkozik azonban, hogy a tudás, az attitǔd és a viselkedés nem vagy igen gyenge összefüggésben áll egymással. Tehát a tudás, a jelen esetben a drogokkal kapcsolatos ismeretgyarapodás nem feltétlenül jár együtt a viselkedés, azaz a droghasználat változásával [37].

Korábbi vizsgálatok már bebizonyították a „self-efficacy”, azaz az énhatékonyság jelentőségét [38-40]. Bukovski és mtsai már 1993-ban bizonyították, hogy a magas énhatékonysággal jellemezhető emberek kevésbé veszélyeztetettek a droghasználat szempontjából [41]. Ha összehasonlítjuk az általunk górcső alá vett DADAprogramot a korábban tanulmányozott programokkal, láthatjuk, hogy egyik program esetében sem mutatkozott jelentős változás az énhatékonyság tekintetében [36]. Meg kell jegyeznünk, hogy a DADA-program esetében az énhatékonyság kiinduló értéke is magas volt, azaz a négyfokú skálán 3 fölötti érték, így valószínúsíthető, hogy a várt eredmény elmaradása ezzel indokolható (5. táblázat).

A 2001-ben vizsgált Drogbusz $(5,90)$ és az általunk feltárt DADA $(5,89)$ az információtartalom tekintetében rendkívül pozitív minősítést kapott [36]. A részt vevő diákok szintén a Drogbusz $(5,05)$ és a DADA $(4,95)$ programokat véleményezték a legmegfelelőbbnek a „sok, régóta foglalkoztatott kérdésre kaptam választ” kijelentés vonatkozásában [36]. Az átadott információkkal való elégedettség tekintetében a legelőnytelenebb értékeléssel a „FÜGE”, a „Tưnj el világ!” és a „Légy észnél!” programok rendelkeznek (6. táblázat) [36]. A pozitív visszajelzések kiváltása szempontjából elengedhetetlen, hogy a programok tervezésekor figyelembe vegyük a célpopuláció igényeit, szociokulturális jellemzőit és azt, hogy milyen a célpopuláció alapállapota a program által befolyásolni kívánt célváltozók tekintetében $[36,42]$.

A Baranya Megyei Rendőr-főkkapitányság programja összességében hatékonynak bizonyult, néhány vizsgált dimenzió esetében azonban nem érte el a várt eredményt a célpopulációban. Nem maradéktalanul sikeres programok kapcsán érdemes végiggondolni az alábbi tényezőket és/vagy azok megfelelőségét:

1) a program végrehajtása;

2) az alkalmazott módszerek intenzitása, az intervenció időtartama, „dózisa”;

3 ) a program kivitelezésére vonatkozó egyértelmű, világos terv vagy vezérfonal megléte;

4) a droghasználat kezdését befolyásoló, speciális (kulturális, társadalmi, pszichológiai) tényezők figyelembevétele a prevenció által megcélzott körben [12,37].

A DADA-program eredményességét jelentős mértékben módosítaná az elsősorban információátadásra és a
6. táblázat A DADA-program eredményeinek összehasonlítása korábbi drogprevenciós programokkal: a diákok véleménye a kapott in- formációkról

\begin{tabular}{lcc}
\hline Programok & $\begin{array}{c}\text { Az egyes állításokkal való } \\
\text { egyetértést kifejező } \\
\text { skálapontértékek átlagai }\end{array}$ \\
\cline { 2 - 3 } & $\begin{array}{c}\text { "Nagyon } \\
\text { sokat } \\
\text { tanultam a } \\
\text { foglalkozás- } \\
\text { ból.” }\end{array}$ & $\begin{array}{c}\text { "Sok olyan } \\
\text { kérdésre } \\
\text { kaptam } \\
\text { választ, ami } \\
\text { már régóta } \\
\text { foglalkozta- } \\
\text { tott.” }\end{array}$ \\
\hline Drogbusz (Budapest, 2001) & 5,90 & 5,05 \\
\hline „Túnj el világ!” (Budapest, 2001) & 4,30 & 3,10 \\
\hline „Légy észnél!” (Budapest, 2001) & 4,16 & 3,69 \\
\hline Kompánia: Drognap (Budapest, 2001) & 4,52 & 4,13 \\
\hline Kék Pont program (Budapest, 2001) & 4,38 & 4,01 \\
\hline Jól-lét prevenciós óra (Budapest, 2001) & 4,70 & 4,21 \\
\hline BOKA (Budapest, 2001) & 5,07 & 4,25 \\
\hline „FÜGE” program (Pécs, 2012) & 3,97 & 3,59 \\
\hline DADA-program (Pécs, 2014) & 5,89 & 4,95 \\
\hline
\end{tabular}

BOKA = Budapesti Orvostanhallgatók Kortársoktató Alapítványa; DADA = Dohányzás, Alkohol, Drog, AIDS; „FÜGE” = Devianciaprevenciós Program 
veszélyek tudatosulására koncentráló tartalom szélesítése és az interaktivitás fokozása.

A prevenciós programok értékelése elengedhetetlen és rendkívül hasznos, ugyanis információt szolgáltat a program lebonyolításának sikerességéról, az elért eredményekről, továbbá tájékoztatást adhat a program hatékonyságáról. A rendszeres monitoring hozzájárul a program hatékonyabb múködéséhez, az esetleges hiányosságok feltárásával segíti azok megoldását [37, 43, 44]. Nem kérdés tehát, hogy a jövőbeli fejlesztések alapvető előfeltétele a prevenciós programok elterjedtségének feltérképezése és hatékonyságuk felmérése.

Hazánkban az iskolai keretek között megvalósított egészségfejlesztési programok minőségbiztosítása érdekében 2013. február 1-jétől bevezetésre került egy szakmai ellenőrző eljárás, melynek lényege, hogy az iskolákban csak olyan prevenciós programok múködhetnek, amelyek ezen az eljáráson megkapják a szakmai ajánlást. A vizsgálatunk lebonyolításának évében, 2014-ben 41 iskolai egészségfejlesztési programajánlás iránti kérelem érkezett a Nemzeti Egészségfejlesztési Intézetbe, ebből 39 volt szerhasználathoz kapcsolódó megelőzési program. A szakmai ajánlást végül 10 drogprevenciós program kapta meg, köztük a kutatásunk alapjául szolgáló DADA-program [34]. Az előzetes megfelelőségtanúsítási rendszer bevezetésének ellenére jelenleg hazánkban nincs megoldva a prevenciós programok teljes körü minőségbiztosítása, miközben a bemeneti (akkreditáció), a nyomon követési (monitoring) és a kimeneti (hatásvizsgálatok, jó gyakorlatok) elvárásokat egyaránt felölelő és összehangoló minőségbiztosítási rendszer mielőbbi kialakítása szükségszerű lenne [45]. Fontos, hogy értékelés hiányában ne végezzünk és közpénzekből ne is finanszírozzunk prevenciót. Ne vezessünk be új, nem tudományos bizonyítékon alapuló módszereket, és merjünk szembesülni az értékelés során esetlegesen felmerülő problémákkal [46]. Egy sikeres, eredményes iskolai drogprevenciós programnak tudományosan igazolt kutatásokra és a célpopuláció drogproblémáinak alapos feltérképezésére kell építenie programját [47-50]. A lényeg, hogy kizárólag olyan programok valósulhassanak meg hazánkban, amelyek rendelkeznek szakmai ajánlással, és megfelelő bizonyítékkal szolgáltak arra vonatkozóan, hogy valóban megelőzik, illetőleg csökkentik a droghasználatot.

Anyagi támogatás: A közlemény az EFOP-3.6.2-162017-00009 Klinikai Kutatások Tematikus Hálózatának Kialakítása és Nemzetköziesítése" pályázat keretében készült.

Szerzői munkamegosztás: D. N.: A vizsgálat tervezése, irányítása, engedélyek beszerzése, irodalomkutatás, a szakirodalom feldolgozása, adatgyưjtés/lekérdezés, adatbázis-kezelés, statisztikai elemzés, a kézirat szövegezése. F. R.: A vizsgálat tervezése, engedélyek beszerzése, a DADA drogprevenciós program megtartása. F. S.: Irodalomkutatás, a kézirat szövegezése, szakmai áttekintés. B. I.: A vizsgálat tervezése, irányítása, engedélyek beszerzése, irodalomkutatás, adatbázis-kezelés, statisztikai elemzés, a kézirat szövegezése, szakmai lektorálás. A cikk végleges változatát valamennyi szerző elolvasta és jóváhagyta.

Érdekeltségek: A szerzőknek nincsenek érdekeltségeik.

\section{Köszönetnyilvánítás}

Köszönettel tartozunk a pécsi székhelyú Apáczai Csere János Általános Iskola, illetve a pécsváradi Kodolányi János Általános Iskola tanárainak és diákjainak, továbbá Paksi Borbálának, Demetrovics Zsoltnak és Rácz Józsefnek.

\section{Irodalom}

[1] United Nations Office on Drugs and Crime. World Drug Report 2017. United Nations Publication. Vienna, 2017; pp. 9-11.

[2] Azzopardi PS, Sawyer SM, Carlin JB, et al. Health and wellbeing of Indigenous adolescents in Australia: a systematic synthesis of population data. Lancet 2018; 391: 766-782.

[3] Cheung YW, Cheung NW. Socio-demographic and psychosocial correlates of drug use. Psychoactive drug abuse in Hong Kong. Life satisfaction and drug use. Springer, Singapore, 2018; pp. 33-55.

[4] Elekes Zs. The European School Survey Project on Alcohol and Other Drugs - 2015. Results in Hungary. [Európai iskolavizsgálat az alkohol- és egyéb drogfogyasztási szokásokról - 2015. Magyarországi eredmények.] Budapesti Corvinus Egyetem, Budapest, 2016. [Hungarian]

[5] Füzesi Zs, Busa Cs. New psychoactive implements, designer drugs and their public health challenges. [Új pszichoaktív szerek, dizájner drogok és népegészségügyi kihívásai.] Népegészségügy 2011; 89: 262. [Hungarian]

[6] Pap Á, Hegedús K. A herointúladagolások üzenete. [The message of the heroin overdoses.] Orv Hetil. 2015; 156: 352-357. [Hungarian]

[7] Gyaramthy VA, Rácz J. Epidemiology of hepatitis C and human immunodeficiency virus infections among injecting drug users in Hungary - what' s next? [A hepatitis C-vírus és az emberi immunhiányt okozó vírus járványtana magyarországi injektáló kábítószer-használók körében - hogyan tovább?] Orv Hetil. 2010; 151: 365-371. [Hungarian]

[8] Fodor M, Sófi Gy. Az ifjúsági drogkarrier veszélyei. [The dangers of drug career in young people.] Orv Hetil. 2015; 156: 18431846. [Hungarian]

[9] Paksi B, Demetrovics Zs. Drug prevention and health promotion in the school. [Drogprevenció és egészségfejlesztés az iskolában.] L'Harmattan, Budapest, 2011. [Hungarian]

[10] Gorman DM, Conde E, Huber JC. The creation of evidence in "evidence-based" drug prevention: a critique of the strengthening families program plus life skills training evaluation. Drug Alcohol Rev. 2007; 26: 585-593.

[11] Coggans N. Drug education and prevention: has progress been made? Drug-Educ Prev Polic. 2006; 13: 417-422.

[12] Rácz J. Efficiency of school drug prevention programs. [Iskolai drogprevenciós programok eredményessége.] Kapocs 2005; 4: 1-21. [Hungarian]

[13] Gabrhelik R, Duncan A, Miovsky M. 'Unplugged': a schoolbased randomized control trial to prevent and reduce adolescent substance use in the Czech Republic. Drug Alcohol Depend. 2012; 124: 79-87. 
[14] Ariza C, Pérez A, Sánchez-Martínez F. Evaluation of the effectiveness of a school-based cannabis prevention program. Drug Alcohol Depend. 2013; 132: 257-264.

[15] Teesson M, Newton NC, Slade T, et al. Combined universal and selective prevention for adolescent alcohol use: a cluster randomized controlled trial. Psychol Med. 2017; 47: 1761-1770.

[16] Shetgiri R, Kataoka S, Lin H. A randomized, controlled trial of a school-based intervention to reduce violence and substance use in predominantly Latino high school students. J Natl Med Assoc. 2011; 103: 932-940.

[17] Hallgren M, Andréasson S. The Swedish six-community alcohol and drug prevention trial: effects on youth drinking. Drug Alcohol Rev. 2013; 32: 504-511.

[18] Faggiano F, Vigna-Taglianti F, Burkhart G. The effectiveness of a school-based substance abuse prevention program: 18-month follow-up of the EU-Dap cluster randomized controlled trial. Drug Alcohol Depend. 2010; 108: 56-64.

[19] Sloboda Z, Stephens RC, Stephens PC. The Adolescent Substance Abuse Prevention Study: a randomized field trial of a universal substance abuse prevention program. Drug Alcohol Depend. $2009 ; 102$ : 1-10.

[20] Brotherhood A, Sumnall HR. European drug prevention quality standards. EMCDDA, Lisbon, 2011.

[21] Brotherhood A, Sumnall HR. European drug prevention quality standards: Final project report. Centre for Public Health, Liverpool, 2011.

[22] Paksi B, Magi A. Drug prevention status(report) - Qualitative research among the vocational service providers. [Drogprevenciós helyzet(jelentés) - kvalitatív kutatás a területen dolgozó szakmai szolgáltatók körében.] Socio.hu 2013; 3: 1-30. [Hungarian]

[23] Faggiano F, Vigna-Taglianti F, Versino E. et al. School-based prevention for illicit drugs' use. Cochrane Database Syst Rev. 2005; (2): CD003020.

[24] Velleman R. Alcohol prevention programmes: a review of the literature for the Joseph Rowntree Foundation (part two) in Children, young people and alcohol: how they learn and how to prevent excessive use. Robert Rowntree Foundation, York, 2009.

[25] Carson-Chahhoud KV, Ameer F, Sayehmiri K, et al. Mass media interventions for preventing smoking in young people. Cochrane Database Syst Rev. 2017; (6): CD001006.

[26] Boncz I, Sebestyen A. Financial deficits in the health services of the UK and Hungary. Lancet 2006; 368: 917-918.

[27] Endrei D, Molics B, Agoston I. Multicriteria decision analysis in the reimbursement of new medical technologies: real-world experiences from Hungary. Value Health 2014; 17: 487-489.

[28] Kriszbacher I, Olah A, Bodis J, et al. Health sciences research in Hungary. CMAJ 2007; 176: 809-812.

[29] Boncz I, Vajda R, Agoston I, et al. Changes in the health status of the population of Central and Eastern European countries between 1990 and 2010. Eur J Health Econ. 2014; 15(Suppl 1): 137-141.

[30] Boncz I, Evetovits T, Dózsa Cs, et al. The Hungarian Care Managing Organization Pilot Program. Value Health Reg Issues 2015; 7: 27-33

[31] Tistyán L, Füzesi Zs. Drug consuption among high school students. The result of a sociological examination. [Kábítószer-fogyasztás a középiskolások körében. Egy szociológiai vizsgálat eredményei.] Fact Intézet, Pécs, 2000. [Hungarian]

[32] Brotherhood A, Sumnall HR. Prevention Profiles 2011. Online Publication. EMCDDA, Lisbon, 2011

[33] Albert F, Tóth O. The young persons' offender and violent behavior: research results and preventive approaches. [A fiatalok bűnelkövetői és erőszakos viselkedése: Kutatási eredmények és prevenciós megközelítések.] MTA TK SZI, Budapest, 2013. [Hungarian]

[34] Csesztregi T, Horváth G, Nyírády A, et al. 2015 National Report to the EMCDDA. "HUNGARY." [2015-ös éves jelentés az
EMCDDA számára. „MAGYARORSZÁG.”] Nemzeti Drog Fókuszpont, Budapest, 2015. [Hungarian]

[35] Danku N, Hegedús A, Boncz I. Attitude change among 18-19 years old boys after "FÜGE" school-drug prevention program. [Attitűdváltozások 18-19 éves fiúk körében a „FÜGE” drogprevenciós program hatására.] Egészség-Akadémia 2013; 4: 214223. [Hungarian]

[36] Paksi B, Demetrovics Zs. The cognition of the drug prevention practice. Evaluation and survey of school drug prevention programs in Budapest. [A drogprevenciós gyakorlat megismerése. Budapesti iskolai drogprevenciós programok felmérése és értékelése.] L'Harmattan, Budapest, 2003. [Hungarian]

[37] Rácz J. Evaluation of the prevention programs. [A prevenciós programok értékelése.] Az Ifjúsági és Sportminisztérium szakmai kiadványa, Budapest, 2001. [Hungarian]

[38] Choi HJ, Krieger JL, Hecht ML. Reconceptualizing efficacy in substance use prevention research: refusal response efficacy and drug resistance self-efficacy in adolescent substance use. Health Commun. 2013; 28: 40-52.

[39] Newton NC, Barrett EL, Swaffield L. Risky cognitions associated with adolescent alcohol misuse: moral disengagement, alcohol expectancies and perceived self-regulatory efficacy. Addict Behav. 2014; 39: 165-172.

[40] Kállai J, Barabás K, Túry F, et al. The medical psychology in Hungary: way of thinking, frame of references and applications. [Az orvosi pszichológia fejlődése hazánkban: szemléleti keretek, határterületek és alkalmazások.] Orv Hetil. 2018; 159: 14551464. [Hungarian]

[41] Bukovski WJ. Meta-Analysis of Drug Abuse Prevention Programs. NIDA Research Monograph 1997; 170: 1-252.

[42] Pénzes M, Czeglédi E, Balázs P, et al. Smoking trajectories among Hungarian adolescents. [Dohányzói életutak magyar serdülő́k körében.] Orv Hetil. 2017; 158: 67-76. [Hungarian]

[43] Hale DR, Fitzgerald-Yau N, Viner RM. A systematic review of effective interventions for reducing multiple health risk behaviors in adolescence. Am J Public Health 2014; 104: e19-e41.

[44] Harris SK, Louis-Jacques J, Knight JR. Screening and brief intervention for alcohol and other abuse. Adolesc Med State Art Rev. 2014; 25: 126-156.

[45] Government of Hungary. The number of H/11798. parliamentary resolution ont he National Drugs Strategy 2013-2020. Pure consciousness, sanity, fight against drug crime. [Magyarország Kormánya. H/11798. számú országgyúlési határozati javaslat a Nemzeti Drogellenes Stratégiáról 2013-2020. Tiszta tudat, józanság, küzdelem a kábítószer-bünözés ellen.] Budapest, 2013. [Hungarian]

[46] Orsini MM, Wyrick DL, Milroy JJ. Collaborative evaluation of a high school prevention curriculum: how methods of collaborative evaluation enhanced a randomized control trial to inform program improvement. Eval Program Plann. 2012; 35: 529534.

[47] Roona MR, Streke A, Marshall D. Substances, adolescence (meta-analysis). In: Gullotta TP, Bloom M. (eds.) Encyclopedia of primary prevention and health promotion. Kluwer Academic/ Plenum Publishers, New York, NY, 2003; pp. 1073-1078.

[48] Porath-Waller A, Beasley E, Beimess DJ. A meta-analytic review of school based prevention for cannabis use. Health Educ Behav. 2010; 37: 709-723.

[49] Gorman DM, Conde E. The making of evidence-based practice: the case of project ALERT. Child Youth Serv Rev. 2010; 32: 214-222.

[50] Ringwalt C, Paschall MJ, Gorman D. The use of one- versus twotailed tests to evaluate prevention programs. Eval Health Prof. 2011; 34: 135-150.

(Danku Nóra,

Pécs, Majtényi Ferenc u. 26., 7625 e-mail: danku.nora@pte.hu) 